\title{
Assessment of Socio-economic and Environmental Outcomes of the Homestay Program at Amaltari Village of Nawalparasi, Nepal
}

\author{
Karuna Karki $^{l *}$, Bir Bahadur Khanal Chhetri ${ }^{2}$, Biraj Chaudhary ${ }^{l}$, Gopal Khanal ${ }^{1,3}$

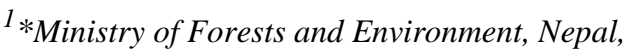 \\ ${ }^{2}$ Institute of Forestry, Tribhuvan University, Pokhara, Nepal \\ ${ }^{3}$ Centre for Ecological Studies, Lalitpur, Nepal \\ *Corresponding author:: karkikaruna08@gmail.com
}

\section{Abstract}

Homestay program is one of key strategies for enhancing rural income and biodiversity conservation. In this study, we assessed the socio-economic and environmental outcomes of a community managed homestay program in Amaltari village of Nawalparasi, Nepal by collecting household level data from the 21 households. We interviewed visitors $(n=60)$ to assess their satisfaction level with the services they are offered. Homestay income was found to have contributed more to the poor households than to the richer ones. Social contributions included increase in community pride, women empowerment and improved community relationship. The contribution in environmental sector was mainly the increase in environmental education and plantation activities. Visitors $(n=60)$ were more satisfied with the hospitality and culture and least satisfied with the available means of communication. Linear regression models did not show any significant effect of age, sex and prior experience of visitors with homestay program on their overall satisfaction score which ranged from -10 to +10 ( $\beta$ age $=-0.003 \pm 0.02$; $\beta$ sex.male $=0.003 \pm 0.02$; $\beta$ first.time $=-0.003 \pm 0.02$ ). Linking the home stay village with markets (e.g., travel agencies) and capacity building training for the homestay owners on management and marketing could be crucial to increase socio-economic and environmental outcomes of the homestay.

Key words: Household income, visitor satisfaction, perception and Tharu community

\section{Introduction}

Homestay is defined as an accommodation where hosts provide foods, accommodation and other related services to their guest and operate it individually or in community groups (MCTCA, 2010). The government's program 'Nepal Tourism Year 2011' boosted up homestay tourism in Nepal. Homestay development is one of key the strategies that have tremendous potentials to achieve the biodiversity conservation and sustainable development goals of ecotourism in rural areas while ensuring greater tourist satisfaction (Lama, 2013). A homestay is staying in some one's home as a paying guest who is provided with accommodation and services by an individual family or local community (Timalsina, 2012). Homestay thus offers the traveler a unique local experience and possibilities of interaction with the host family. It offers chances to the governments for expanding economic activities to remote areas and develops alternative sources of income for rural people and generates resources for nature conservation (Gangotia, 2013). 
In Nepal, homestay program has received tremendous adoption over the last decade, particularly in rural areas with natural beauty. As the homestay operation in small scale requires limited knowledge and skills and physical resources, it has great potential in Nepal for involving rural people in tourism business and improving their livelihood whilst preserving the nature and local rural lifestyle, culture and identity. The total number of homestays in Nepal in 2013 according to Nepal Tourism Board was 160. And with registration of 51 new homestays in all these districts, Nepal had 211 homestay facilities in the year 2014, 217 in 2015 and 271 in 2016 (NTS, 2016). Community involvement in home stay operation provides a job opportunity and improves local quality of life (Bhuiyan et al., 2011).

Homestay became more popular after the government of Nepal officially introduced the homestay tourism program with the 'Homestay Regulation 2067' in 17th August 2010 (Devkota, 2008). While homestay approach to local ecotourism management has received recognition in conservation fronts, limited scientific information is available on its socioeconomic outcomes, effectiveness and challenges. This limited information on outcomes and effectiveness of homestay program has been major bottleneck for its effective planning and replication in new area. If the homestay program is to be successful, it is extremely important to have a source of information to provide a feedback system to the planners and managers based on empirical studies.

In this study, we aimed to generate some information from one of the most important ecotourism destinations in Nepal, which is buffer zone community of the Chitwan National Park. We asked three basic questions in this study: (1) what are the initial motivations for adopting homestay program?

(2) what contribution does homestay program have in economic, environmental and social conditions of the families running homestay? and (3) what is the level of satisfaction of visitors from services offered by the homestay program and what factors are affecting their satisfaction level? We hypothesize that socio-economic characters of the visitors will influence their satisfaction level for the services offered by homestay owners. Our results are expected to provide crucial information for effective planning of the homestay program in Nepal.

\section{Materials and Method}

\section{Study Area}

The study was conducted in the Amaltari buffer zone of Chitwan National Park, Nepal (Fig. 1). In this area, homestay program was introduced with 20 households of Tharu Community at Agyauli-5 on May 19, 20 in 2013. The village is typically dominated by Tharu community, a unique indigenous community of Nepal. The study area was selected as it is inhabited by the indigenous Tharu community, which is famous for its cultural richness and traditions. From 20132015 , the area was visited by 26700 ecotourists, 53 of which were international visitors. Terai Arc Landscape (TAL) program is working with local community in home-stay development. TAL supported US\$ 490.2 (NRS 50, 000 per household) in 2013 to start a homestay program and generate income from this program for local community. 

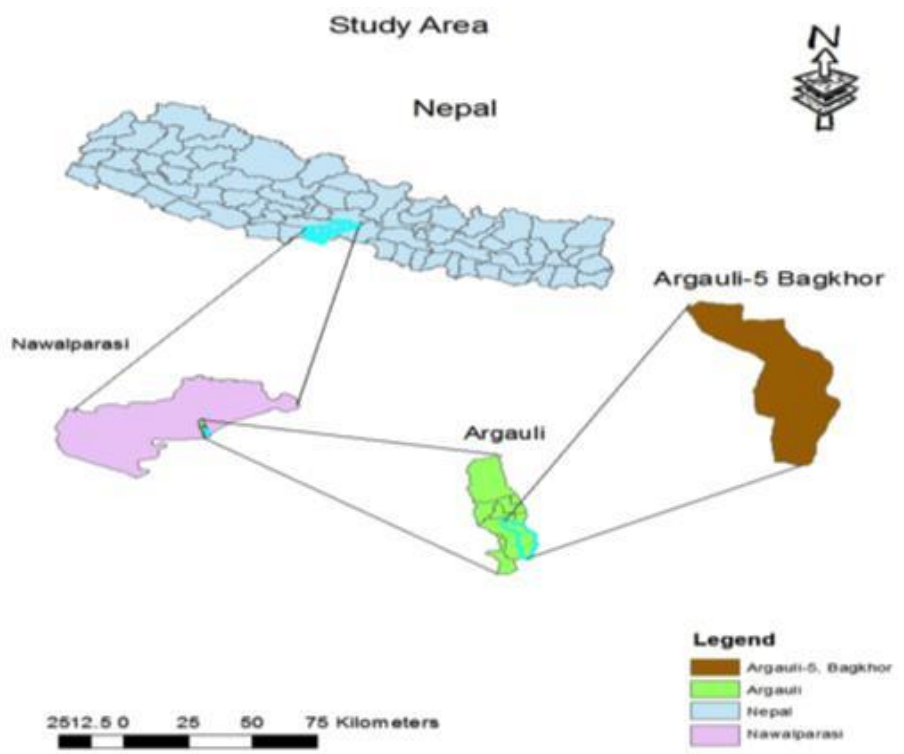

Figure 1: Amlatari village within Nawaparai district which a fall under the Chitwan National Park buffer zone area.

Sampling Method

\section{Homestay owner's survey}

We interviewed one family member (who was available during time of interview) from each of 21 homestay households operating homestay program in Amaltari village. We asked them a series of questions pertaining to income generated from the homestay program, their experience with this new sort of environment friendly business.

\section{Group discussion}

We also had three informal discussions with the members from Amaltari Homestay Management Committee, Terai Arc Landscape -Nepal, Chitwan National Park, and Amaltari Buffer Zone User Committee to get information on contribution of homestay to different aspects of community development and environment and to get their suggestions to improve the program. The main aim of group discussion was to get insights into overall status and issues (e.g., sustainability, pollution control, etc.) involved in the homestay program and also to figure out local communities' recommendation for its betterment.

\section{Visitors' satisfaction survey}

Altogether, 60 guests (16 female and 44 male) were interviewed between 27th Sept 2015 and 12th Dec 2015 to understand their satisfaction towards different services including hospitality and security services offered by homestay owners. All of the 60 guests were national visitors. Because of earthquake that struck Nepal in 2015, there was not a single international visitor during the survey. We also wanted to examine the influence of different socio-economic factors on the satisfaction level of visitors with homestay services. To quantify the satisfaction of visitors, we asked them ten questions related to the services provided to them by the homestay operators. With this information, we then developed a satisfaction score for each visitor. We were particularly interested in examining whether age and sex of the visitors influence their 
satisfaction level. We could not include the other important variables, the origin of visitors (national and international) due to low sample size and because we did not have international visitors in our sample. We also wanted to assess if visitors who had visited the homestay area and stayed there earlier were more likely to be satisfied with the services offered by the homestay owners.

\section{Data Analysis}

We used descriptive statistics (e.g., mean, frequency) to analyse the household level homestay income and its contribution to their livelihood. Bar charts and tables were used to summarize sampling, and socio-economic information of the respondents. To analyse the influence of different socio-economic characteristics of visitors on their satisfaction level of homestay services, we developed a composite satisfaction score based on ten questions for each respondent visitor. The response for each respondent thus could range from -10 to +10 , where negative value represents non-satisfaction, 0 represents neutral neither satisfied nor non-satisfied and positive value represented satisfied with the homestay services. We wanted to assess the relative importance (direction and magnitude of the influence) of different socio-economic factors in influencing visitor satisfaction towards the services offered by homestay owners. We thus developed seven plausible linear Regression Models with Gaussian error distribution and identify link function to examine the single and additive influence of explanatory variables on satisfaction level (scores) of the visitors. Models were ranked using the Akaike information criterion adjusted for small samples (AICc) (Burnham and Anderson, 2002). Models with delta AIC less than 2 are likely to have greater support for the underlying data. We used R package "MuMin" (Barton, 2016) to perform model averaging of all candidate models, to estimate $95 \%$ confidence intervals of the estimated slope parameter for each variable, and accepted statistical significance at $\alpha=0.05$ (Burnham and Anderson, 2002). The relative importance of each predictor variable was determined by summing the Akaike weights of the models containing this factor. Confidence intervals that included zero indicated no influence of predictor variable on response variable. All analyses were carried out in R 3.1.2 (RCT, 2016).

\section{Results and Discussion Results}

\section{Motivation for homestay}

Our results showed that improvement in family income was the initial motivating factor for initiating homestay program followed by use of free time in constructive work (Fig. 2). Although majority of the households expressed their agreement on contribution of homestay in preservation of culture, women empowerment and social unity, none of these households expressed any of these two as primary drivers for their involvement in homestay business.

\section{Motivation for homestay program}

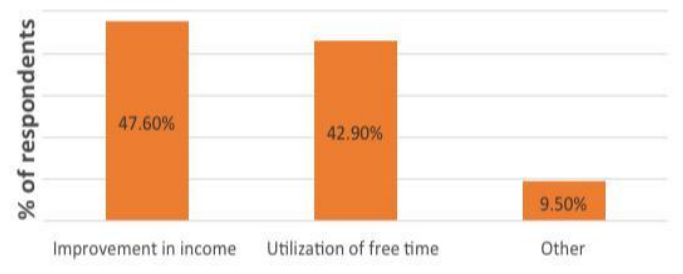

Motivation factors

Figure 2: Motivation for the homestay 
Contribution of homestay in economic sector

We found that contribution of homestay income was more for poor people $(70 \%)$ than for rich households (30\%) (Table 1). However, in absolute terms rich people were found to generate more income than poor people. The monthly income from homestay for poor was NRs.20000 (US\$ 196) whereas richer households were found to have earned monthly more than NRs. 20000 (US\$ 196).
We found that homestay contributed more to increase in the income of local people and for creating jobs for local people, which has enhanced the standard of living. All the homestay owners mentioned that yearly income has increased and homestay program has created jobs. Few owners had felt that the home stay program contributed in infrastructures development (19\%) and generated fund for investment in other community development activities (14\%) (Fig.3).

\section{Contribution of homesaty on economic sector}

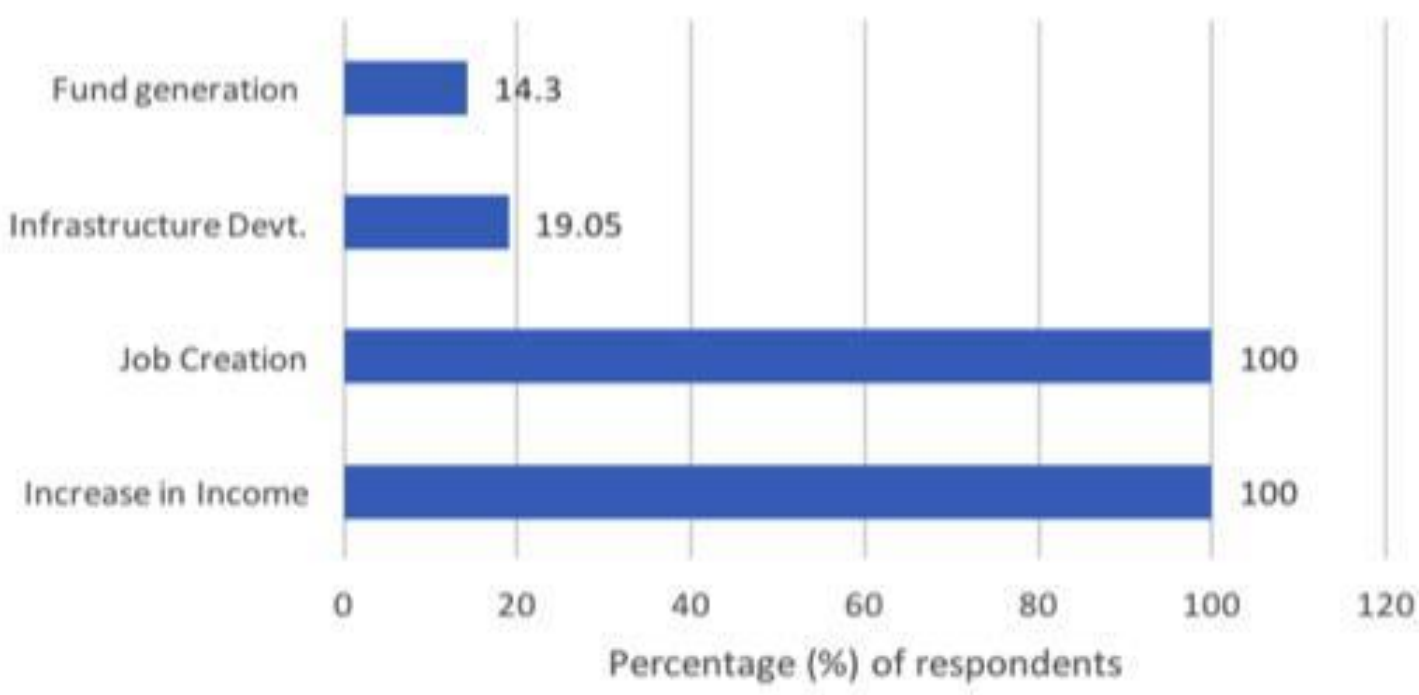

Figure 3: Contribution of homestay on economic sector

Table 1: Annual average per capita income (Rs) of the respondents by wealth class.

\begin{tabular}{cccc}
\hline Wealth Class & $\begin{array}{c}\text { Annual average } \\
\text { per capita income } \\
\text { from (Rs) }\end{array}$ & $\begin{array}{c}\text { Monthly average } \\
\text { per capita homestay } \\
\text { income (Rs) }\end{array}$ & $\begin{array}{c}\text { Share of homestay } \\
\text { in total income }\end{array}$ \\
\hline Rich & 7468.66 & 2486.73 & $33.29 \%$ \\
\hline Poor & 2716.5 & 1917.71 & $70.59 \%$ \\
\hline
\end{tabular}


Contribution of homestay in social sector

We found that homestay had increased women empowerment and community pride of almost all of the local homestay owners. All respondents mentioned that homestay program had improved social-cohesion, cooperation and relationship among local communities. All homestay owners said that homestay program enhanced local community pride and women empowerment while about only $20 \%$ stated that it helped in providing better education to children (Fig. 4). We further found that homestay had provided opportunities for women and youth within their home to earn some money and support their family. The program had also generated capacity building and skill development opportunities like basic cook

\section{Contribution of homestay in} environment and biodiversity conservation sector

We found that home stay program had increased conservation awareness, fostered environment conservation, waste management and increased plantation activities. All respondents stated that they had experienced increase in conservation awareness whereas only $38 \%$ believed that homestay program could reduce pollution in the surrounding areas (Fig. 5).

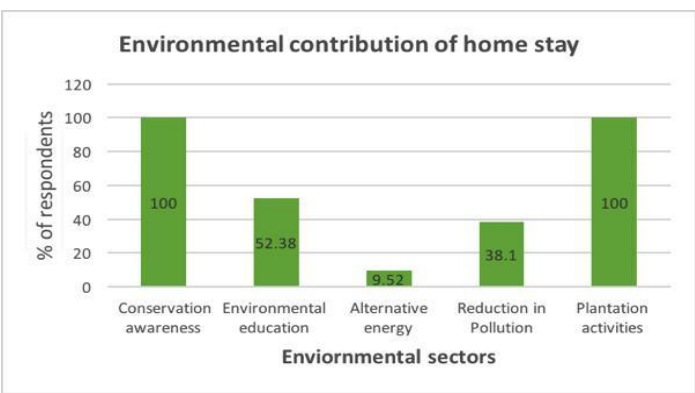

Figure 5: Contribution of homestay in environmental sector training, handicraft training and hospitality training given to women and youths of Amaltari by organizations like World Wildlife Fund (WWF), Buffer Zone Management Committee and Taragaun Bikas Samiti.

\section{Homestay contribution on social sector}

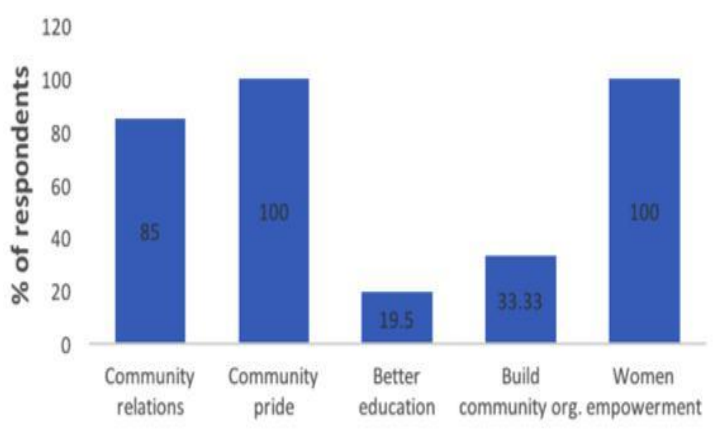

Sectors of contribution

Figure 4: Contribution of homestay in social sector

\section{Visitors' Level of Satisfaction}

All visitors were satisfied with the hospitality and services offered by the homestay owners (Table 2). About $83 \%$ of the visitors were happy with the local place and environment where about $80 \%$ liked local culture and dance. Only $13.3 \%$ of visitors were satisfied with communication services in homestay area whereas $21.7 \%$ and $48.3 \%$ liked the tourist information center and transportation facility respectively (Table 2). Regression models did not show any significant effect of age, sex and prior experience of homestay program on overall satisfaction score of the visitors (Table 3). Model averaged betacoefficients of all the examined three variables did not have significant influence on satisfaction scores $\quad(\beta a g e=-0.003 \pm 0.02$; $\beta$ sex.male $=0.003 \pm 0.02 ; \beta$ first.time $=-0.003$ \pm 0.02 ). Single models of age, sex and first. time had comparable support the data (Table 2). Moreover, all three single models (model 
1-Age; Model 2-Sex; Model 3-First.time) more or less similar support for the data had comparable Akaike weight $(\mathrm{Wi}=0.24)$, which suggested that all three variables had (Table 3).

Table 2: Level of visitors' satisfaction

\begin{tabular}{|c|c|c|c|c|c|}
\hline \multirow[b]{2}{*}{ S.N } & \multirow[b]{2}{*}{ List of things or activities } & \multicolumn{4}{|c|}{ Level of Satisfaction } \\
\hline & & $\begin{array}{c}\text { Satisfied } \\
(\%)\end{array}$ & $\begin{array}{c}\text { Neutral } \\
(\%)\end{array}$ & Dissatisfied (\%) & Wt. Mean \\
\hline 1 & Service and hospitality & 100 & 0 & 0 & 1 \\
\hline 2 & Food and taste & 60 & 40 & 0 & 1.4 \\
\hline 3 & Culture and cultural dance & 80 & 20 & 0 & 1.2 \\
\hline 4 & Tourist information center & 21.7 & 70 & 8.3 & 1.87 \\
\hline 5 & Transportation facility & 48.3 & 30 & 21.7 & 1.73 \\
\hline 6 & Communication & 13.3 & 80 & 6.7 & 1.93 \\
\hline 7 & Attraction and activities & 71.7 & 23.3 & 5 & 1.33 \\
\hline 8 & Security & 78.3 & 21.7 & 0 & 1.22 \\
\hline 9 & Price of food and services & 58.3 & 41.7 & 0 & 1.42 \\
\hline 10 & Local place and environment & 83.3 & 16.7 & 0 & 1.17 \\
\hline
\end{tabular}

\section{Achievement and Problems of} Amaltari Homestay

Our group discussion $(\mathrm{n}=12)$ and formal informal interaction with homestay owners and local communities showed that the homestay had provided direct employments to 53 members, mostly women and the capacity of this homestay was 84 beds and this accounts for 30 thousand 6 hundred and 60 person-nights annually. Despite insufficient promotion, around 27 thousand guests had visited the place from May 2013 to Dec 2015. The homestay business in Amaltari was influenced by seasons. The months of August, October, November, December and January (5 months) were peak business season with highest flow of visitors in November. According to the records maintained by AHMC, total income from May 2013 to Dec 2015 was US\$ 132352.94. Some external challenges for operating homestay business in Amaltari were road, transportation, power, water, communication, internet, security, hospital and market. Besides, households had to overcome their own internal challenges. They didn't have enough capital to improve their housing facilities. They needed more skills like hospitality training, cook training, tourist guide training, formal and non-formal education to improve their service. These external and internal challenges had made homestay a difficult business in Amaltari village. 
Table 3: Linear regression models describing the satisfaction of visitors towards homestay facilities

\begin{tabular}{llcccc}
\hline Model & K & AICc & DAICc & loglink & Wi \\
\hline Age & 2 & 247.00 & 0.00 & -121.38 & 0.243 \\
\hline Sex & 2 & 247.00 & 0.00 & -121.38 & 0.243 \\
\hline First.time & 2 & 247.00 & 0.02 & -121.39 & 0.241 \\
\hline Age+Sex & 3 & 249.10 & 2.16 & -121.35 & 0.083 \\
\hline Age+first.time & 3 & 249.20 & 2.18 & -121.37 & 0.082 \\
\hline Sex+first.time & 3 & 2249.20 & 2.19 & -121.37 & 0.081 \\
\hline Age+Sex+first.time & 4 & 251.40 & 4.43 & -121.34 & 0.027 \\
\hline
\end{tabular}

The variables were ranked according to the Akaike information criterion adjusted for small sample size (AICc). Model parameters include satisfaction (score), Age, Sex, and whether the visitor had visited the area before (first.time). $\mathrm{K}$ is the number of parameters, $\triangle \mathrm{AICc}$ is the difference between the AICc value of the bestsupported model and successive models, and Wi is the Akaike model weight.

\section{Discussion}

Our results suggested that monetary income and utilization of the free time were main motivating factors for the adoption of homestay as an eco-sensitive business in Amalatari, Rupandehi. A study performed by the Nepal Rastra Bank Nepalgunj in 2015 in Dallagaun Home stay in Bardiya National Park also found that income was the initial motivation factor for homestay business, similar to our study (NRB, 2015). Homestay had come up as a major source of income to the people involved in this program improving their livelihood and enhancing their livelihood opportunities. We found that share of homestay income in total household income for poor $(70 \%)$ was greater than for the rich $(30 \%)$, as it was one of the major source of income for the poor. This showed that the contribution of homestay income was more important to the poor than to the rich. In the study conducted by Bhudathoki (2013) in Ghalegaun, Lamjung, Nepal, one of the famous home stays in western Nepal also found that poor family were more benefited from homestay tourism, tourism income contributed about $34 \%$ share to total income of such group. Both the findings contrasted with the hypothesis that rich and elite people always take advantage of such income program supported by government (Naomi, 2001).

In our study, about 71.4 percent of the respondents mentioned that they saved 25-50 percent of income from homestay while 28.6 percent of the respondent said that they saved more than 50 percent of income from homestay. In similar study by Nepal Rastra Bank, 2015 in Dallagaun, Bardiya National Park found that 22.7 percent households had saved below $20 \%$ of their income whereas 59.1 percent households had saved between $20 \%$ to $65 \%$ and rest 18.2 percent households had saved above 65\%. (NRB, 2015). It appeared that homestay owners in both the study areas earned more or less similar amount of income. Results of our focus group discussion suggested that homestay had improved the relations of women within the 
community by making them economically independent and empowered. The local management committee for the homestay program said that 10 percent of total income was allocated for cultural activities.

Overall, our results suggested that community based home stay program in Amaltari had not only improved income of local residents, but also had fostered greater environmental education and biodiversity conservation awareness among them. This program had also empowered local community youths and women through skills development and leadership training programs. Moreover, there had been improved social-relationships among local residents after the initiation of homestay program. We had expected that old age respondents who had visited homestay earlier would likely to have overall higher satisfaction. However, our results do not provide any reliable estimates to make any inference on the influence of the explanatory variables. Since the estimated slope parameters for the covariates had standard errors associated with them, we are not confident about the direction of influence of our covariates. Although the slope parameter or beta coefficient of the age is negative ( $\beta$ age $=-0.003 \pm 0.02$ ), we could not conclude that older people were less satisfied with the homestay service because the standard error associated with the estimated beta coefficient is larger than the beta estimate suggesting non-significant influence. Similar results apply to the variables sex and first-time. One reason could be that age, sex and first-time variables did not have any influence on satisfaction level. However, it is also possible that our sample size $(n=60)$ was too small to capture the variability in visitor's satisfaction. Visitors were more satisfied with the service and hospitality, culture and local environment and least satisfied with the visitor information center and means of communication. Increase in services, quality and activities were more important to increase in the level of satisfaction than decrease in price.

\section{Conclusion}

Income and utilization of free time were the main motivating factors for these households for taking homestay profession. The extent of contribution of homestay in economic sector indicated that homestay contributed more to increase the income of local people and to create jobs for local people followed by improvement of infrastructures and generating fund for investment in other community development activities. The extent of contribution of homestay in social sector showed that homestay contributed more to community pride, women empowerment and improved the relationship of people within the community followed by enhanced standard of life, developed community based organization and provided better education. In environment sector, homestay contributed more to plantation activities and awareness of conservation activities followed by fostered environment education and study of potential pollution. Visitors were more satisfied with the service and hospitality, culture and local environment and less satisfied with the visitor information center and means of communication. Increase in services, quality and activities are more important to increase the level of satisfaction than decrease in price.

The key conclusion of our study is that there is still a great scope for enhancing the contribution of the homestay program in fostering biodiversity conservation and 
improving local livelihood. To realize this potential, there is a need for a comprehensive homestay policy and continued government support programs. We suggest that homestay policy should facilitate homestay registration, reduce homestay taxation and formulate longterm policies to promote homestay systems throughout the country promoting biodiversity conservation and improving the livelihood of local people hand in hand. Linking the home stay village with markets (tours and travel agencies in the capital and through webs) and the potential foreign visitors could be vital in increasing contribution of homestay to local livelihoods and biodiversity conservation. Organizing homestay management trainings including sanitations and hygiene techniques to the households may help to improve the overall

\section{References}

Barton, K. 2016. MUMIN: multi-model inference. $R$ package version 1.15.6., http://CRAN.R-project.org/

package $=$ MuMIn quality of the homestay program and also contribute to biodiversity conservation.

\section{Acknowledgements}

We thank the Department of National Park and Wildlife Conservation, Nepal for providing the research permit to conduct this study. We also thank the Amaltari Homestay Management Committee and Amaltari Homestay operators who agreed to participate in this study and assisted in field data collection. We are grateful to Dr. Suresh Shrestha for his continuous support and Miss Dikshya Pokhrel for her guidance. We gratefully acknowledge the financial assistance provided by the Hariyo Ban Program, World Wildlife Fund Nepal.

Budhathoki, B. 2013. Impact of Homestay Tourism Devkota, T. P. 2008. Homestay Tourism in Nepal, on Livelihood: A Case Study of Ghale Guan. A Thesis Submitted to Department of NORAGRIC for the Partial Fulfilment of Master Degree in 'Master in International Relation', viewed on October 2015, Gangotia, A. 2013. Home Stay Scheme in Himachal https://brage . bibsys . no/xmlui/ handle/11250/187939.

Ecotourism Development in East Coast Economic Region. American Journal of Applied Science, 8: 540546.

Gorkhapatra Sansthan, viewed on 14th November 2012, http://www. gorkhapatra.org.np/rising.detail. php?article_id=45767\&cat_id=7.

Pradesh: A Successful Story of Community Based Tourism Initiatives (CBTIS). Global Research Analysis,

Burnham, K.K.P. and Anderson, D.R.D. 2002. Model 2(2): 206-207.

Selection and Multimodel Inference:

A Practical Information-Theoretic Lama, M. 2013. Community Homestay Programs Approach (2nd ed.), Ecological Modelling. as Form of Sustainable Tourism Development in Nepal. A Thesis Submitted to Centria University Bhuiyan, M.A.H., Siwar, C., Ismail, S. M. and Islam, R. 2011. The Role of Home Stay for of Applied Sciences for Degree Programme in Tourism, viewed on 
August 2015, https://www.theseus.fi/ bitstream/handle/10024/68913.

MCTCA. 2010. Ministry of Culture, Tourism and Civil Aviation, Homestay Working Procedure 2067, viewed on 10th August 2015, http://www.tourism.gov. np/uploaded/pdf/homestayworkingprocedure-2067.pdf.

Naomi, M. S. 2001. Practical Strategies for Pro-poor Tourism: A Case Study of Pro-poor Tourism and SNV in Humla District, West Nepal.

NRB. 2015. A Study on Dallagaon Homestay and Its Sustainability, Nepal Rastra Bank. viewed on August 2015,https://www. nrb.org.np/red/publications/study reports/Study_Reports-A_Study_ on_Dallagaon_Homestay_and_Its_ Sustainability.pdf.
NTS. 2016. Ministry of Culture, Tourism and Civil Aviation, Nepal Tourism Statistics. Viewed on August 2017, http:// www.tourism.gov.np/downloadfile/

Nepal\%20Tourism\%20statistic Final2016_1498990228 pdf.

RCT. 2016. R: A Language and Environment for Statistical Computing Vienna: $R$ Foundation for Statistical Computing. $R$ Core Team, Royal Mountain Travel Nepal, Nepali Homestays December 18, 2011, viewed on Nov 2015, http://blog.royalmt.com.np/nepalihomestays/.

Timilsina, P. 2012. Homestay Tourism Boosts Ghale Gaon's Economy, viewed on September 2015, http://www.gorkhapatra. org.np./rising.detail.php? Article_ $i d=23200 \&$ cat_id $=4$. 